\title{
Estimation of dry matter, crude protein and starch values in mixed feeds by near-infrared reflectance (NIR) spectroscopy
}

\author{
Research Article \\ Volume: 4, Issue: 3 \\ December 2020 \\ Pages: $125-130$
}

\begin{abstract}
Hasan ATALAY ${ }^{1} *$, Fatih KAHRIMAN ${ }^{2}$, FIrat ALATÜRK ${ }^{2}$
1. Department of Animal Nutrition and Nutritional Diseases, Faculty of Veterinary Medicine, Balikesir University, 10145, Balıkesir, Turkey. 2. Department of Field Crops, Faculty of Agriculture, Çanakkale Onsekiz Mart University, 17100, Çanakkale, Turkey. H. Atalay ORCID: 0000-0002-5744-7538. F. Kahriman ORCID: 0000-0001-6944-0512, F. Alatürk ORCID: 0000-0003-3394-5855.
\end{abstract}

\begin{abstract}
This study aims to determine the levels of dry matter, crude protein, and starch widely used in ruminant feeding, in dairy and beef cattle mixed feeds based on the measurements taken from two different Near-Infrared Reflectance (NIR) devices. The chemical analyses of the mixed feed samples used in the study were performed and the reference values (REF) were determined. In the research, two different NIR devices, a Benchtop-NIR and a Portable-NIR, were used and the nutrient values of mixed feeds were analyzed with these devices. It was determined that there were statistically significant differences between the reference method and NIR results for protein and starch content. Although the differences between the mean values were significant, the reference analyses results and NIR measurements were similar in some ways. According to the correlation coefficients calculated between the reference analyses with Benchtop-NIR and Portable-NIR devices, there was a weak correlation in the dry matter content, while a strong positive correlation existed in the protein ( $r=0.72$ for Portable, $r=0.93$ for Benchtop NIR) and starch content. In the study, 30 different mixed feed (dairy cattle feed, beef cattle feed) values that are commonly used in ruminant feeding were measured.
\end{abstract}

Keywords: mixed feed, starch, near-infrared reflectance (NIR)

\section{Article History}

Received: 27.8.2020

Accepted:22.11.2020

Available online:

23.11.2020

DOI: https://doi.org/10.30704/http-www-jivs-net.786427

To cite this article: Atalay, H., Kahriman, F., Alatürk, F. (2020). Estimation of dry matter, crude protein and starch values in mixed feeds by near-infrared reflectance (NIR) spectroscopy. Journal of Istanbul Veterinary Sciences, 4(3), 125-130 Abbreviated Title: J Ist Vet Sci

\section{Introduction}

Animal products are aimed to be obtained by using vegetables in ruminant feeding. Consuming animal products is critically important for a healthy society. However, the nutritional content of mixed feeds varies according to the feed crude materials used. Minimizing the cost of feed, the most important cost of the livestock sector, is vital for livestock enterprises. The feed should not only be economical but also have quality standards. Mixed feeds, prepared for livestock, are widely used in cattle and sheep feeding. As there is a deficit in roughage in our country, the nutritional needs of cattle and sheep are provided with mixed feeds. Factories produce concentrated feed and carry out quality analyses to supply the nutrients required for animals. The nutritional content of the mixed feeds changes according to the nutritional content of the

*Corresponding Author: Hasan Atalay

E-mail: hasanatalay@balikesir.edu.tr crude material.

Starches, in the class of Non Structural Carbohydrate (NSC), are the main energy sources for lactating dairy cows and it is recommended to be 23$30 \%$ in the ration. The amount of starch in the ration is important to avoid nutritional diseases such as acidosis (Usta and Saçaklı, 2013). Considering the living and productivity shares of animals, various nutrients are needed. They need to consume carbohydrates and fats to obtain energy, protein for amino acids, vitamins for enzyme activities, and minerals for nervous and muscular systems (Freeman, 2003). Carbohydrates are the most important energy source of animals. $70-80 \%$ of dry matter in plants consists of carbohydrates (Butler et al., 2003). 
Carbohydrates include sugar, starch, cellulose, and lignin. They consist of carbon, hydrogen, and oxygen compounds. Carbohydrates are divided into two as simple and complex carbohydrates. Simple carbohydrates are found in cereal grains and contain starch and sugar, whereas complex carbohydrates are found in feed and are very difficult to digest. Complex carbohydrates consist of cellulose and lignin. They can be divided into two as fibrous and non-fibrous compounds. The fibrous part consists of NDF, cellulose, lignin, and hemicellulose, while the nonfibrous part consists of starch, sugar, and pectin (Harris, 1993).

Carbohydrates have a significant share in rations. In fact, it constitutes $60-70 \%$ of the energy required for daily milk production. The starch in the rations directly affects milk yield. As a matter of fact, the milk yield of the cattle that were fed with high starch content (32.9\%) was found to be significantly higher than that of low starch content (24.9\%) (MacGregor et al., 1983).

Starch consists of glucose sugars that are bonded together. It is digested in both the rumen and the intestines. Depending on the types of starch and processing method, it can be digested at the rate of 6 $60 \%$ in 1 hour in the rumen. Starch is one of the main sources of energy and microbial protein for rumen microbial fauna. Excessive starch and sugar fermentation may cause rumen acidosis, which leads to a decrease in rumen $\mathrm{pH}$, rumen microbial activities, feed intake, and yield (Hall, 2010).

The study aims to compare the results of the reference analyses with the results obtained from
Portable- and Benchtop-NIR devices for dry matter, crude protein, and starch levels determined by chemical analysis in dairy and beef cattle mixed feeds.

\section{Materials and Methods}

In the study, 30 different mixed feed values that are commonly used in dairy and beef cattle mixed feeding were measured. The mixed feed samples of $0.5 \mathrm{~kg}$ were freshly taken from the factories, brought to the laboratory in air-tight bags, and kept at $-20{ }^{\circ} \mathrm{C}$ until analysis. The mixed feed samples were milled (Retsch ZM 200 ultra centrifugal mill) in a $1 \mathrm{~mm}$ screen for analysis.

Reference Analysis (REF, Chemical Analyses): The reference analyses of the chemical mixed feeds used in the study were carried out according to the method reported for the dry matter (method 934.01), crude protein (method 954.01), and starch (method 920.40) (AOAC, 1990).

NIR Spectroscopy Measurements: NIR measurements were performed on two different NIR devices. One of these devices was the Benchtop-NIR (Spectrastar 2400D, Unity Scientific, USA) while the other was the Portable-NIR (Dinamica Generale Agri NIR Analyzer, Italy). In the Benchtop-NIR device, the spectrum data of $1 \mathrm{~nm}$ frequency between 1200-2400 nm were collected separately from the feed samples (dairy and beef feeds) as dry matter for making spectral measurements and determining the feed quality. INGOT calibration model (Maize Silage and Forage, Unity Scientific, USA) was applied to the spectral data to determine the dry matter, crude protein and starch values of mixed feed samples. Feed samples for

Table 1. Descriptive statistics of observed traits for reference analysis and NIR measurements

\begin{tabular}{llccc}
\hline Statistic & Trait & Benchtop-NIR & Portable-NIR & Reference (chemical) \\
\hline \multirow{3}{*}{ Mean } & Dry Matter & 88.5 & 89.0 & 88.7 \\
& Protein & 15.9 & 21.2 & 18.8 \\
& Starch & 29.2 & 12.6 & 23.9 \\
\hline \multirow{3}{*}{ Min } & Dry Matter & 87.6 & 87.3 & 87.2 \\
& Protein & 11.7 & 17.6 & 13.1 \\
& Starch & 19.3 & 10.0 & 15.2 \\
\hline \multirow{3}{*}{ Max } & Dry Matter & 89.9 & 90.2 & 90.5 \\
& Protein & 19.7 & 25.6 & 23.3 \\
& Starch & 43.2 & 16.6 & 39.7 \\
\multirow{3}{*}{ STD } & Dry Matter & 0.66 & 0.79 & 0.78 \\
& Protein & 1.74 & 1.93 & 2.49 \\
& Starch & 5.52 & 1.73 & 5.16 \\
\hline
\end{tabular}


measurements in the Portable-NIR device were placed in the measuring chamber of the device and spectral measurements were made. After the measurement, the dry matter, crude protein, and starch values were determined with calibration defined in the device.

Statistical Analysis: The data obtained from the study were analyzed with the SAS statistical software (SAS, 1999). Descriptive statistics on quality parameters of mixed feed were obtained with the proc MEANS procedure. Variance analysis was used to determine the effect of sample, device, and plant types from which the mixed feed was produced on the analysis results. The difference between the reference analyses of the feed samples as dry matter and fed and the results obtained from both NIR devices was compared with the Kruskal-Wallis test. Correlation analysis was used to examine the relationship between the data regarding the quality of feed obtained from NIR devices in the sample group. Pearson correlation was used in correlation analysis, and analyses were carried out with the proc CORR command in the SAS program. Correlation test results were shown graphically and the relationship between the NIR estimates and reference analyses was explained.

\section{Results}

According to the statistical analysis, it was observed that there was no statistically significant difference between the Portable-NIR and Benchtop-NIR with reference measurements based on the dry matter content of the mixed feed. Therefore, it was seen that dry matter measurements with NIR devices can substitute the results of reference analysis and both methods can be used in the determination of the dry matter in mixed feeds, which is important in terms of time, labor, and material. It was also understood that the difference between the mean dry matter obtained from the Benchtop-NIR device and Portable NIR device was significant. However, it can be observed in Figure 1 that the difference was very low. Therefore, the value obtained from the Benchtop-NIR device was $89.5 \%$, while it was $89.0 \%$ in the Portable NIR device (Table 1).

The mean values of starch content and differences between NIR devices and reference analysis are presented in Table 1 and Figure 1. According to the mean values, the Benchtop-NIR had the highest protein content $(29.2 \%)$, which was close to the reference analysis results (23.9\%), while the lowest value was obtained from the Portable-NIR device (12.6\%) (Table 1). Those differences were found to be statistically significant (Figure 1). When the Portable
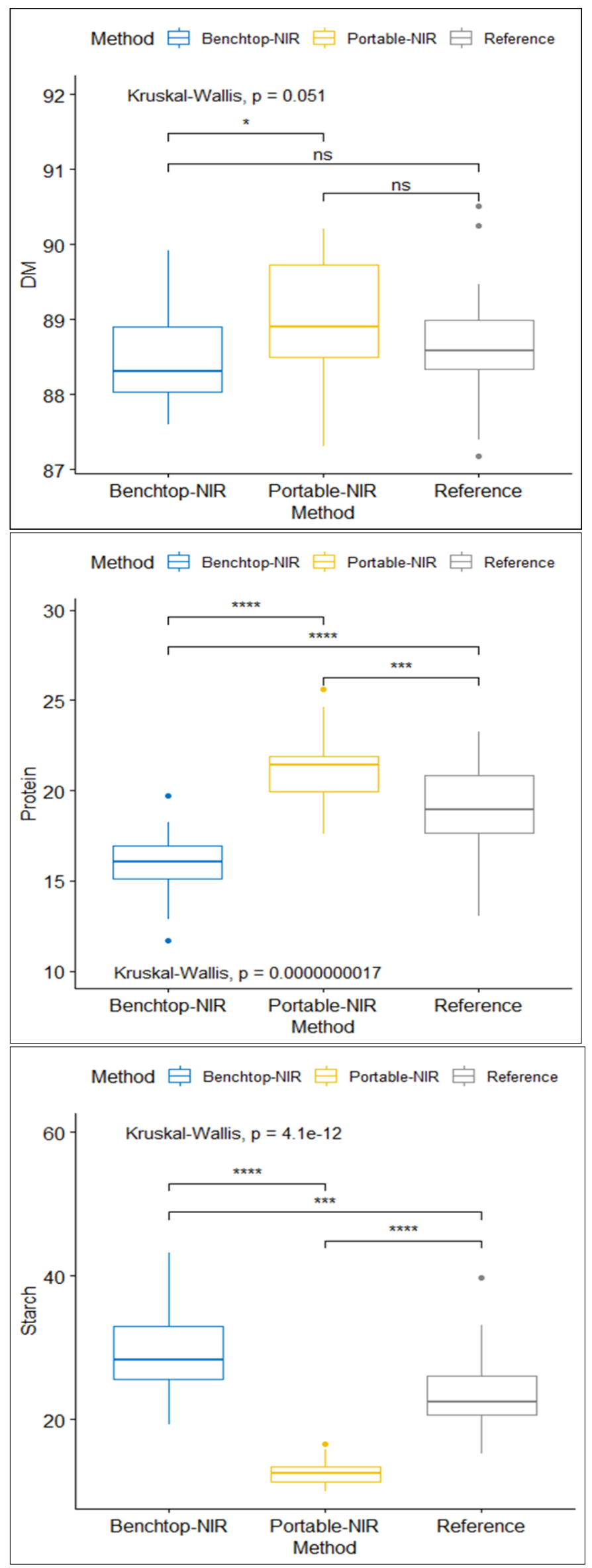

Figure 1. Comparison of reference and NIR analyses for investigated traits. 


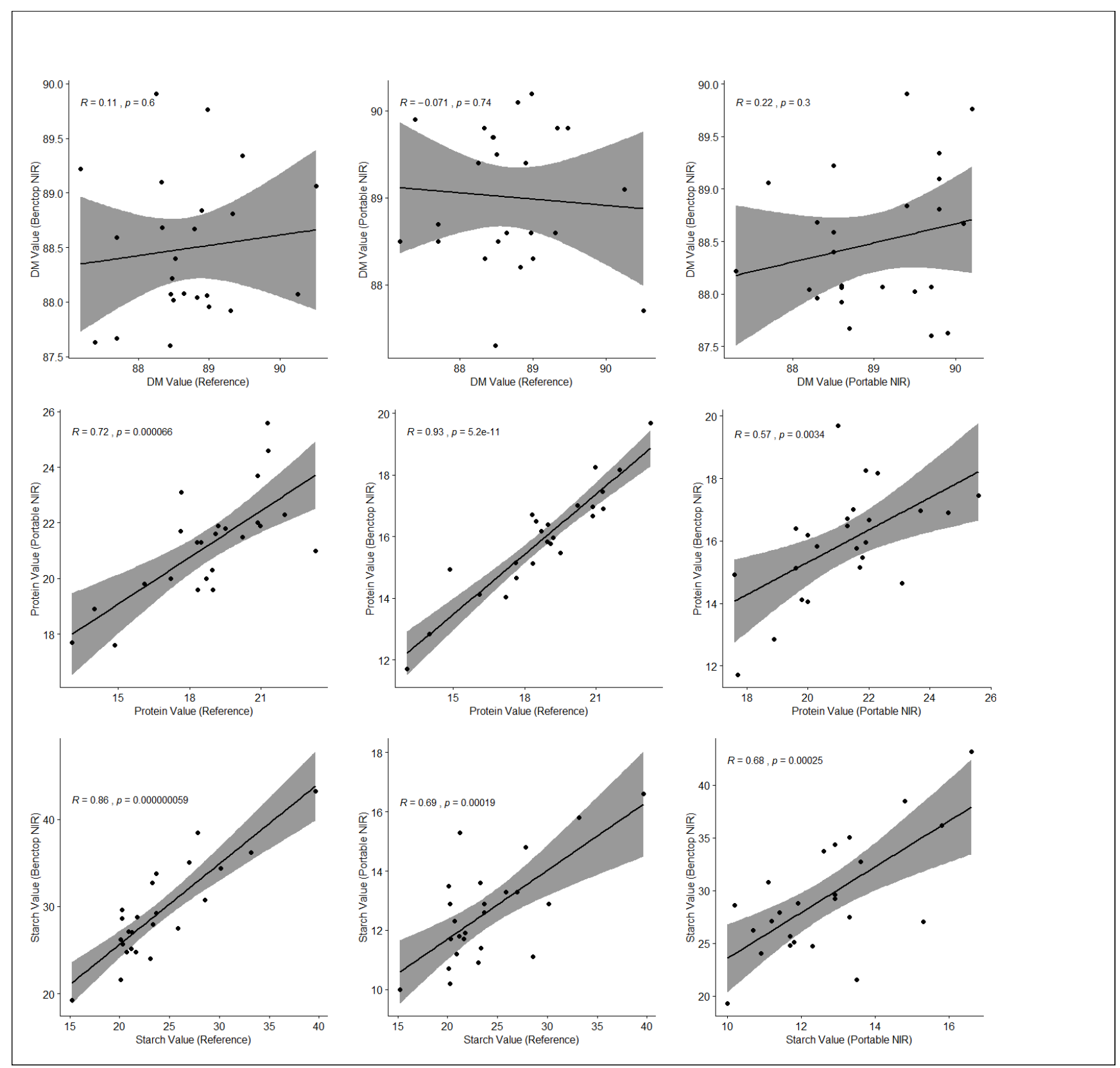

Figure 2. Correlation the plots among reference and NIR analysis results.

NIR device was compared with the Benchtop-NIR device, it yielded much lower mean scores than the reference analysis, which was noteworthy.

It was also observed that the mean scores obtained from the Benchtop-NIR device for protein ratio $(15.9 \%)$ were lower than the reference analyses (18.8\%), while the mean scores for the Portable-NIR device were higher than that of the reference analyses (Table 1). It was seen that there were statistically significant differences between the results of three separate analyses (Figure 1). Compared to the reference analysis, it was observed that the means obtained from NIR devices had a difference of approximately $3 \%$.

Considering sample level similarities for starch content, it was discovered that the Benchtop NIR device had a higher correlation $(r=0.86, p<0.01)$ compared to the Portable NIR device as in protein ratio. The correlation coefficient $(r=0.69)$ calculated between the reference analysis and the Portable NIR device was similar to the coefficient calculated for the NIR devices (Figure 2).

\section{Discussion}

$\mathrm{CP}$ was found as $18.19 \pm 0.27 \%$ in dairy cattle mixed feeds produced in Trakya whereas it was found as $14.11 \pm 0.33 \%$ in beef cattle mixed feeds produced in the Marmara region (Çelik et al., 2003). In a study conducted in the city of Van, CP was found as $7.40 \%$ for barley, $30 \%$ for cottonseed meal, and $16 \%$ in wheat bran (Baytok et al., 2000).

CP of dairy and beef cattle mixed feeds ranged from 13.66 to $21.91 \%$. CP values of barley, wheat, corn, and oats were found between $9.26-12.30 \%$ (Abaş et al., 2005). CP was found between 7.19-7.94\% for corn, $8.46-11.15 \%$ in barley, $10.26-13.39 \%$ for 
wheat, $13.52-13.83 \%$ for wheat bran (thick), and 14.20-15.23\% in wheat bran (Göngör et al., 2008). It was also found that that $\mathrm{CP}$ was $10.56 \%$ for barley, $10.92 \%$ in wheat, $8.38 \%$ in corn, $12.79 \%$ for wheat bran, $29.24 \%$ for sunflower seed meal, $32.02 \%$ for cotton seed meal, and $44.98 \%$ for soybean meal (Alp et al., 1996).

In barley varieties, the starch concentration determined by the calculation method (not chemical analysis) was found between 51-64\% (Maruz and Çelik, 2020). In addition, the starch content of triticale and wheat varieties measured with NIT SystemInfratec 1241 grain analyzer was found between 62.46-64.65\% (Kızılgeçi and Yıldırım, 2017).

In a study in which the chemical compositions of poultry feeds used in poultry nutrition were investigated using the chemical and NIRS method, a weak relationship was found in terms of starch content $(R 2=0.269)$ while there was a significant relationship between dry matter and crude protein content (R2=0.7239; 0.9549) (Karaman and Erdemir, 2018).

Crude protein and starch content in the total mixed ration (TMR) were estimated by NIRS with good accuracy $(R 2>0.85)$ in proportion to low standard estimation errors (Mentink et al., 2006).

In our study, the results of the correlation analysis performed to examine the differences between the mean values at the sample level are presented in Figure 2. Although there was no statistically significant difference between the methods in terms of dry matter content, the similarity between the different NIR devices and sample analysis results of the reference analyses was quite low according to the correlation analysis. Therefore, it was seen that it would not be correct to use these methods as substitutes at the sample level.

According to the results obtained for the protein ratio, it was observed that there was a positive and significant relationship between the results obtained from both NIR devices and the reference analysis. In addition, the results obtained from the Benchtop and Portable-NIR devices showed high similarity. At the sample level, the Benchtop-NIR device had the highest similarity $(r=0.93, p<0.01)$ whereas a lower similarity $(r=0.72, p<0.01)$ was determined between PortableNIR and reference analysis results. Protein is one of the most successfully detected contents in different samples of vegetables (Baye et al., 2006). Therefore, in this study, the results obtained at the sample level were higher for the protein ratio, which was expected. However, it was observed that the success of the Benchtop- and Portable-NIR devices in determining the protein ratio of the fattening feed was different.
The differences between the results obtained from different spectroscopy devices in this study are related to the measurement methods and the calibration models used. The scanning range and frequency of the Portable-NIR device are lower than the Benchtop NIR. However, there may be differences in the calibration and sample compatibility of these estimation models although global calibration models are used in both devices. As a matter of fact, in a study conducted by Tran et al., (2010), the prediction success of local and global models in different feed sources was compared and local models were found to yield more successful results compared to global models.

\section{Conclusion}

In this study, the relationship between the reference analysis and the results obtained from the NIR devices having two different properties was investigated by determining the crude protein, starch, and dry matter content of mixed feeds. The results showed that although there were significant differences between the protein and starch content with the reference analyses, there was a remarkable similarity at the sample level according to the correlation analysis. Comparing the sample analyses, it was observed that NIR devices can be used to determine the protein and carbohydrate content of mixed feeds provided that some conversion coefficients need to be developed for the detection. It is useful to carry out different studies for the development of those conversion coefficients by using more samples in future research.

\section{Conflict of interest}

Authors have no conflict of interest to declare.

\section{References}

Abaş, i., Özpınar, H., Kutay, H. C., Kahraman, R., \& Eseceli, H. (2005). Determination of the metabolizable energy (ME) and net energy lactation (NEL) contents of some feeds in the Marmara region by in vitro gas technique. Turkish Journal of Veterinary and Animal Sciences, 29(3), 751-757.

Alp, M., Koçabağlı, N., Kahraman, R., Yetim, M., \& Şenel, H. S. (1996). Kanatlı beslenmesinde bullanılan yem maddelerinin ve karma yemlerin besin maddeleri ve enerji kapsamları yönünden değerlendirilmesi. Istanbul Üniversitesi Veteriner Fakültesi Dergisi, 22(1), 9-22.

AOAC (1990). Association of Official Analytical Chemists, 16th ed. Washington, D.C., USA.

Baye, T. M., Pearson, T. C., \& Settles, A. M. M. (2006). Development of a calibration to predict maize seed composition using single kernel near infrared spectroscopy. Journal of Ceracel Science, 43, 236- 
Baytok, E., Muruz, H., Bolat, D., \& Aksu, T. (2000). Mera'da otlayan süt ineklerine farklı düzeylerde protein intiva eden karma yem verilmesinin süt verimi ve kompozisyonuna etkisi. Y.Y.Ü. Veteriner Fakültesi Dergisi, 11(1), 117-120.

Butler, L. D, Cropper, J. B., Johnson, R. H., Norman, A. J., Peacock, G. L., Shaver, P. L., \& Spaeth, K.E. (2003). Livestock nutrition, husbandry, and behavior. National range and pasture handbook, 1st ed. United States Department of Agriculture Natural Resources Conservation Service.

Çelik, K., Ertürk, M. M., \& Ersoy, i. E. (2003). Quantitatively Investigating some quality characteristics of compound feeds and feedstuffs sampled out of different feed mills, Akdeniz Üniversitesi Ziraat Fakültesi Dergisi, 16(2), 161-168.

Freeman, S. (2003). Biological Science. Prentice Hall.

Göngör, T., Başalan, M., \& Aydoğan, İ. (2008). Kırıkkale yöresinde üretilen bazı kaba yemlerin besin madde miktarları ve metabolize olabilir enerji düzeylerinin belirlenmesi. Ankara Üniversitesi Veteriner Fakültesi Dergisi, 55, 111-115.

Hall, M. B. (2010). Non-fiber carbohydrates. Technical Services Nutritionist F.A.R.M.E. Institute, Inc., Homer, NY.

Harris, B. (1993). Florida Cooperative Extension Service. Nonstructural and structural carbohydrates in dairy cattle rations. Gainesville: Florida Cooperative Extension Service, Institute of Food and Agricultural Sciences, University of Florida.

Karaman, M., \& Erdemir, S. (2018). Kanatlı hayvanların beslenmesinde kullanılan bazi karma yemlerin kimyasal kompozisyonunun near infrared reflektans spektroskopi (NIRS) ile belirlenmesi. Black Sea Journal of Agriculture, 1(2), 24-28.

Kızılgeçi, F., \& Yıldırım, M. (2017). Bazı tritikale (X
Triticosecale Wittmack) genotiplerinin verim ve kalite özelliklerinin belirlenmesi. Türkiye Tarımsal Araştirmalar Dergisi, 4(1), 43-49.

MacGregor, C. A., Stokes, M. R., Hoover, W. H., Leonard, H. A., Junkins, L. L., Sniffen, Jr. C. J., \& Mailman, R. W. (1983). Effect of dietary concentration of total nonstructural carbohydrates on energy and nitrogen metabolism and milk production of dairy cows. Journal of Dairy Science. 66(1), 39-50.

Mentink, R. L., Hoffman, P. C., \& Bauman, L. M. (2006). Utility of near-infrared reflectance spectroscopy to predict nutrient composition and in vitro digestibility of total mixed rations. Journal of Dairy Science, 89(6), 2320-2326.

Muruz, H., \& Çelik, C. (2020). Bazı arpa (Hordeum vulgare L.) çeşitlerinin in vitro gaz üretimi, organik madde sindirilebilirliği, besin maddeleri içerikleri ve enerji değerlerinin karşılaştrııması. Anadolu Tarım Bilim. Dergisi, 35, 133-139.

SAS Institute 1999, SAS V8 User Manual, SAS Cary, NC. Tran, H., Salgado, P., Tillard, E., Dardenne, P., Nguyen, X. T., \& Lecomte, P. (2010). Global and local predictions of dairy diet nutritional quality using near infrared reflectance spectroscopy, Journal of Dairy Science, 93(10), 4961-4975.

Usta, M., \& Saçaklı, P. (2013). Süt ineklerinin beslenmesinde nişastanın önemi ve düşük nişastalı rasyonlarla besleme stratejileri. Erciyes Üniversitesi Veteriner Fakültesi Dergisi, 10(2), 125-133. 